\title{
The housing and economic development debate revisited: economic significance of housing in developing countries
}

\author{
Godwin Arku
}

Received: 6 September 2006/ Accepted: 6 September 2006/

Published online: 17 October 2006

(C) Springer Science+Business Media B.V. 2006

\begin{abstract}
Should housing improvement be part of economic development strategies? Must housing improvement wait until high-economic growth is attained? How much priority should be given to housing in view of the limited resources in lessdeveloped countries? What are housing benefits in economic development vis-à-vis other economic investments? These questions have generated heated debates, both in the literature on development problems and in planning and practice in the $1950 \mathrm{~s}$ and 1960s. This paper draws on the accumulated body of knowledge resulting from past experiences in research and policy to revisit the earlier debates, survey the main lines of argument and reassess the economic potential of housing. It then attempts to generate broad policy considerations. The main contention of this paper is that in light of past and present evidence, the housing sector needs to be given serious consideration in economic growth strategies.
\end{abstract}

Keywords Housing $\cdot$ Economic development $\cdot$ Developing countries

\section{Introduction}

Views on the economic significance of housing have long been characterized by fashions, both in the literature on development problems and in planning and practice. For much of the 1950s and 1960s, during which development was largely identified with economic growth, development economists tended to reject any widespread investment in housing as a meaningful development strategy. This was mainly due to its supposedly high capital-output ratio in comparison with other investments. During the same period, housing "reformers" challenged this notion for a variety of reasons. Initially, they justified investment in housing primarily in social terms: conditions were poor, and social needs were pressing. Over time, other

G. Arku $(\bowtie)$

Department of Geography and Environmental Studies, Wilfrid Laurier University, 75

University Avenue West, Waterloo, Ontario, Canada N2L 3C5

e-mail: garku@wlu.ca 
scholars and international agencies came to appreciate the economic aspects of housing. They also began to appreciate the role that housing could play in planned economic development in such areas as employment, improvement in health and productivity and savings.

Several key questions defined the earlier debates. Should housing improvement be part of economic development strategies? Must housing improvement wait until high-economic growth is attained? How much priority should be given to housing in view of the limited resources in less-developed countries? What are housing benefits in economic development vis-à-vis other economic investments? Even after five decades of discussion and analysis there are no conclusive answers to these questions. Gradual changes in attitudes and perceptions have occurred, and new evidence has emerged from research and policy efforts, but these have not been well-documented. Moreover, housing institutions and policies have been key components of the economic development strategies in the new industrialized countries (NICs) in the Asia Pacific region. In contrast, the role of housing in advancing economic growth has not attracted much policy attention in other parts of the developing world. This paper revisits the earlier debates, surveys the main lines of argument and reassesses the economic potential of housing. The paper then attempts to generate a broad perspective on policy considerations.

Development theory, including development economics, emerged as a distinct subfield of study after 1945. Section one of this paper outlines the character of development theory at that time and highlights the role that its advocates assigned to the housing sector. One of two viewpoints that emerged followed the mainstream attitude in downplaying the role of housing, but advocates felt compelled to concede its importance in specific settings. This viewpoint is discussed in section two. The second view, discussed in section three, provides a broader perspective on the housing sector and the factors that might contribute to economic growth. Subsequent sections highlight some evidence from the literature that indicates the economic significance of housing. Finally, this paper presents concluding comments and propositions for public policy.

\section{Early development theory and the role of housing}

For much of the 1940s and 1950s, development was largely equated with economic growth. At the time many development economists believed that lack of capital was the main constraint on development. Consequently, capital formation was the dominant development approach, and this approach was supported by prominent theoretical works (Harrod, 1939; Domar, 1947). Low levels of productivity, income and savings were regarded as primary causes of under-development. For example, Nurkse (1953: p. 5) observed that in the developing world "There is the small capacity to save, resulting from the low level of real income. The low-real income is a reflection of low-productivity, which in turn is largely due to the lack of capital". Lewis (1954), like Nurkse, emphasized the importance of capital in promoting economic growth. Others advocated capital formation as a necessary condition for an economy to experience rapid growth and to reach the "maturity" stage (Rostow, 1960). Industrialization was embraced as an integral part of development because it would provide employment for the bulk of the population in urban areas. Emphasis 
was also placed on the construction of roads, power plants and communications facilities. Developing countries emerging from colonial rule pursued capital formation growth strategies with zeal. Given this dominant postwar prescription for economic development, an important question arises concerning the way its advocates perceived the role of housing in the development process. In the early postwar period, this issue generated a heated debate-both in the development literature and in policy circles.

Housing investment was not regarded as a meaningful development strategy. It was seen as an unproductive investment, and its role was downplayed and labelled variously as a "resource-absorber", a "consumer good" and "social overhead". Critics, whom Solow (1955: p. 52) dubbed the "down-to-earth, hard fact analysts", believed housing had an extremely high capital-output ratio, especially when compared with investment in other sectors. These critics pointed out that housing investment contributed to inflation, used valuable foreign exchange resources, exerted pressure on the balance of payments position and tied up resources for a very long period of time (cf. Weissman, 1955; Harris \& Gillies, 1963). The general assumption was that resources were limited and that there was a need to develop strategies that would use scarce resources in the most productive and efficient manner, mainly in sectors (e.g. industry) that promised quick returns and that enhanced the productive capacity of an economy. Housing was not seen as an activity that could achieve this goal. As Strassman (1970a: p. 505) observed: "Financing housing without raising productivity was throwing money into a bottomless pit." For example, Charles P. Kindleberger, a leading economist of that time, questioned the desirability of investing in housing when resources were scarce (Robinson, 1963: p. 122). Housing investment "was regarded as the classic means of slowing economic growth" (Gilbert \& Gugler, 1992: p. 133) or as Drakakis-Smith (1997: p. 799) puts it, "loses out to investment in industry or industrial infrastructure" (see also Abrams, 1964: p. 106).

In mainstream economic thinking, housing improvement was a by-product of economic growth; hence it could be postponed until the late stages of development. The critics' belief at the time was that if economic growth and good administration were encouraged, the housing problem would eventually disappear. Nerfin, a former advisor at the UN Economic Commission for Africa, argued that with respect to the African housing problem, "difficulties can only be solved by development, and by the industrialization on which development is based" (1965: p. 555; see also Harris \& Gillies, 1963: p. 93).

Such views were also held in policy circles. Speaking at an MIT conference in 1953, Sir Percy C. Spencer, the Australian ambassador to the United States, commented that the Australian government had many urgent issues to which it needed to attend, and house building was not one of them. He believed that "The more important thing is to help people to obtain the facilities to increase production and progressively, they will thereby solve the problem of housing on their own" (cited in Kelly, 1955: p. 18). Similar thinking was also apparent in the policies of such institutions as the World Bank whose substantial portion of investment went into the creation of physical capital.

Even though some experts supported investment in housing on the grounds that it would absorb unemployed labour, critics insisted that unemployed human resources could be used more productively in sectors other than housing (Burns \& Grebler, 1977: p. 97). The critics also argued that population growth alone did not 
justify investing scarce resources in housing. They denied the notion that planned housing programmes could be used as a tool to achieve an even geographic pattern of economic development. They argued that housing programmes targeted at urban centres could serve as incentives for migration to those areas and could eventually lead to uneven development. Although some proponents of housing development stressed the link between housing and health, these critics stated that no (or at best little) correlation existed between poor housing and social ills (Freeman, 1975). Critics saw housing as a passive element in the development process. In their view, the relationship between housing and economic development was asymmetrical; that is, economic growth would automatically lead to housing improvement.

Because of their unique positions as consultants for institutions such as the World Bank and advisors to governments of the less-developed countries, critics of housing investment had far-reaching influence on policy decisions. Most Third World policy-makers ignored, or assigned a low priority to, housing in National Development Plans (NDPs), hoping that the housing problem would disappear as the pace of economic development quickened. For example: "Most NDPs prepared in Latin America during the 1950s and early 1960s emphasized industrial development, paying little attention to agricultural development and none to human settlement" (Hardoy, 1978: p. 162). And at a Regional Seminar on Housing and Community Improvement in Asia and the Far East, A. M. Lorenz, a reporter from Bombay, stated that with respect to India, there were no "facts...to substantiate that housing directly affects productivity" (UN EcoSoc, 1955: p. 58).

A UN (1969) study of NDPs of more than 40 developing counties revealed that only a limited number of plans paid attention to the relationship between housing and other sectors of the economy. Even in countries where some attention was paid to the issue, policy-makers most often justified policy principles on social considerations and political legitimacy-not on its economic potential. The case of Nigeria illustrates this point vividly. During the development of the country's first NDP (1962), Koenigsberger (1970: p. 395) observed that the plan "sets firm output targets for agriculture, manufacturing industries, roads, harbours, railways, water, etc. but treats housing as a Social Overhead", and "Social Overhead was interpreted as a necessary evil". According to Koenigsberger (1970: p. 395): "Nigerian investors were not told how, when and where to invest in housing." In general, the majority of the early development plans treated the production of housing as "something to be tolerated rather than desired" (Burns \& Tjioe, 1967: p. 86).

This neglect, or welfare perception, of housing-exemplified in the countries mentioned above-was found throughout the developing world from the 1970s to the 1990s. Its prevalence was underlined in a World Bank sector policy paper that stated: "in the great majority of developing countries, this perception has yet to take hold. Governments too often perceive housing solely as a welfare issue, requiring the transfer of physical or financial resources to households unable to house themselves adequately" (World Bank, 1993: p. 11). Not surprisingly, government expenditures on the housing sector in most developing countries are most often negligible, typically accounting for only about $2 \%$ of total government expenditures (IMF, Government Financial Statistics, 1986; Buckley \& Mayo, 1988; World Bank, 1993; Arku, 2006). 


\section{Moderates}

Two alternative views emerged in the late 1950s. The first group, dubbed the "moderates", followed the mainstream in downplaying the economic significance of housing but felt compelled to concede its importance in specific settings. This group argued for a limited amount of investment in certain types of residential construction but on the condition that it would contribute to industrial development. The moderates also drew attention to the importance of the construction sector in economic development but were sceptical about giving undue attention to housing vis-à-vis other competing investments.

Two early exponents of the moderates' viewpoint were Leo Grebler and Max Millikan, both of whom spoke at a conference on housing and economic development at MIT in 1953. Grebler, who worked for the UN in the 1960s as a housing consultant, argued that investment in housing should not be made on the basis of need because developing countries needed practically everything and that the need for housing was no different from many others. He noted that investment should be made only if it had potential to advance productivity, stating: "the only road to greater material welfare is through greater economic productivity" (Grebler, 1955: p. 30). Grebler believed better housing could contribute to the advancement of productivity, for example by improving health and increasing longevity. He also believed that it was vital in attracting labour for the operation of industries. His colleague, Millikan, who also spoke at the MIT conference, emphasized that resources were scarce and the many competing needs placed a limit on the amount of resources that could be allocated to housing. As such there was the need to invest in housing only as a necessary complement to other investments, for example in a "new company town" where investing in workers' housing could make a factory productive by providing an incentive for workers to settle close to the factory (Millikan, 1955: p. 24).

Arguing along the same line, Howenstine, who was I.L.O.'s housing advisor in the 1950s, acknowledged the limited productive capacity of less-developed countries and the need to utilize those resources in the most efficient manner. Howenstine (1957) argued that resources should be invested in sectors that promised the greatest returns, notably factories. However, he admitted that strict adherence to the criterion of productivity should not be the only basis for public policy since other factors, such as improved worker conditions and better housing, were equally necessary to raise productivity. He acknowledged that this might lead to higher productivity by improving health and reducing absenteeism.

The views of scholars in the moderates' group who studied and elaborated on the place of construction in national development are uniquely important. Among them are Turin (1970, 1974, 1978a), Hable-Selassie (1978), Gorynski (1978), Drewer (1980), Kafandaris (1980) and Wells (1984, 1985). Unlike the classical economists who viewed construction as an ancillary activity, these authors showed a full appreciation of the importance of construction in development. This is clearly evident in the words of Turin, who stated: "the construction industry can play a central role in the development strategy of many less developed countries, provided it is recognized as a valid sector of production" (1978a: p. 5). These authors argued that construction must be among the lead sectors in national economy, and they mentioned the sector as a major component of investment, an important contributor to 
Gross Domestic Product (GDP) and Gross Fixed Capital Formation (GFCF) and as a necessary strategy for employment creation.

At the same time, some of these scholars raised questions about the undue emphasis on the importance of housing vis-à-vis other societal needs. Turin, for example, questioned the argument regarding the priority of housing, stating: "let us at least stop assuming things, for instance, that human settlements should be given priority in national planning. Priority above what? Work? Health? National security? Law and Order?" (1978b: p. 169). Samuelson (1955) and Peattie (1979) also expressed cautious opinions regarding this issue. Both argued that the housing problem was easily recognizable because of its visibility (physical nature) as opposed to other "invisible" needs, such as inadequate nutrition. Samuelson stated that "It is easy for an observer to see the inadequacies of the London slums. It is much harder to see the vitamins that the pre-war Cockney occupants were not getting" (Samuelson, 1955: p. 36). On the basis of this, Samuelson wondered "if the alleged inadequacy of housing is not an optical illusion" (Samuelson 1955: p. 36). The authors recognized the importance of housing provision as well as the constraints inadequate housing might pose to development. In their view the importance of housing does not necessarily mean that housing concerns should assume higher priority over other, equally important sectors.

A major weakness in the moderates' suggestion was the assumption that resources should be allocated to housing only if it had the potential to contribute to industrial development. This suggested a residual role of housing in relation to other sectors. In the past, this reasoning did not entertain the possibility that housing might generate economic benefits, and it retarded the formulation of comprehensive housing policies in most Third World countries. Several studies have revealed that the broader economic gains of housing investment in the national economy can be substantial; residential construction is a productive activity that can accelerate the pace of economic growth and development (see Rodwin, 1987; Mera \& Heikkila, 1999; Tu, 1999; Phang, 2001; Arku \& Harris, 2005).

Another debatable suggestion made by the moderates was that housing was a "necessary adjunct" to industrial development. This idea implied that qualitatively improved housing was beneficial for workers, for example in company towns where better housing would raise their labour efficiency, improve health status and reduce the number of days lost from work. If one accepts these premises, then a relevant question to ask is: why is housing improvement not also beneficial in larger urban centres where most members of the population are informal sector workers? Unfortunately, the moderates did not consider the larger segment of urban population, including informal settlements where investment might conceivably be made to enhance rapid development. Informal housing activities have demonstrated the capacity to generate economic benefits. Indeed, the majority of the well-documented economic benefits of housing investments, including those that relate to home-based enterprises (HBEs) and rental housing, were found in the informal neighbourhoods (Tipple, 1993; Kumar, 1996; Sinai, 1998; Chen, Sebtab \& O’Connell, 1999). Thus, a second major criticism of the moderates' proposal is their inadequacy to tackle housing problems facing the national economy with regard to low-priorities that were accorded to the housing sector. Housing cannot contribute substantially to economic development without broader attention to its place within an overall urban and national economy. The moderates' suggestion (that priority should be given to housing investment only if it has the potential to advance industrial productivity) 
was equally deficient. Such an argument simply reinforces the critics' suggestion that investment be made in "productive" activities while housing remains a by-product of economic growth.

\section{Proponents}

The second viewpoint that emerged recognized housing as being potentially important to economic growth. Advocates of this viewpoint rebutted suggestions that housing should be postponed until the late stages of development. One of the earliest and most fervent proponents at the time was Catherine Bauer Wurster, who shaped US public housing policy in the 1930s. At the MIT conference, she posed the question: "must any widespread improvement in the home environment wait until the basic economy can provide higher incomes, an efficient building industry and capital, labour and materials not needed for immediately productive types of enterprise?"' (Bauer, 1955: p. 39).

Aware of the stereotypic image of housing, the earliest proponents were very defensive and expressed strong counter-arguments at conferences and in the literature. Unlike the development economists, the proponents came from diverse academic backgrounds. They argued that housing was productive, stimulative and a contributor to development. In particular, they argued that investment in residential construction could have broader implications for national economies. Studies that focused on the role of housing in economic development included those of Abrams (1964), Currie (1966), Burns and Tjioe (1967), Grimes (1976), Wegelin (1978) and Strassman $(1982,1985)$. These early studies have been supported by several recent studies (see, Tipple, 1987, 1993; Spence, Wells, \& Dudley, 1993; UNCHS/ILO, 1995; Mera \& Heikkila, 1999; Tu, 1999; Phang, 2001; Arku \& Harris, 2005). These studies focus on employment and income effects, household savings, labour productivity, health influence and investments and growth effects of housing investment.

The work of leading housing intellectuals Abrams and Turner, who worked in advisory capacities for the UN and lived in a number of developing countries, helped to pioneer the view that housing must be understood within a broader context. These two well-known advocates of "self-help housing" were interested in the appropriateness of housing policies and projects, particularly those that met the exact needs of low-income households. They believed that housing in low-income areas was complex and should be understood from the perspective of what it did for people. This conviction led Turner (1976) to propose the idea that housing must be understood not for what it is (a physical product), but for what it does (a process). Essentially, Turner argued for a change in housing policies. He understood the economic benefits of housing and knew that investment in housing could play a pivotal role in development. Turner observed: "the owner or possessor-occupier can use his house...as a shop, workshop, or rental property. Often families will deliberately build their houses as duplex apartments-one apartment for themselves, the other for rent or for occupation by the second generation" (1968: pp. 357-358).

Abrams had expressed a similar view earlier and pointed out specific economic benefits of housing. He noted: "the building of homes is 'economic' in that houses in the less developed areas are often the small production centres...Housing also plays a major role in stimulating employment, directly and indirectly" (1964: p. 109). 
Abrams further stated that "once housing is accorded as an integral part of any development program, a nation is then better poised to plan its most effective and most economically practical production" (Abrams, 1964: p. 113). Currie (1966: p. 140), another proponent of this viewpoint, also recognized the importance of housing in the industrialization programme, which must be taken into account when formulating development strategies. Currie stated that "To encourage industrialization, we must start with housing and urban public services". He belonged to a small group of development economists who expressed scepticism over undue emphasis on capital formation. In his "Columbia Plan", Currie suggested, "We should give priority to consumer goods (including housing) rather than to heavy and capital goods industries" (Currie 1966: p. 140).

By the early 1970s there were more pronouncements. The proponents of the idea that housing contributes to economic growth articulated their views in the academic literature and in policy circles. These scholars played a prominent role in highlighting the economic role of housing in development. They attempted to counteract what they believed to be the misconceived ideas about housing, and they provided evidence to support their claims regarding the importance of housing in the national economy. For example, several empirical studies addressed the supposedly "nonproductive" character of housing. The earliest study was by Burns and Tjioe (1967) and was conducted at two sites: Pine Ridge in South Dakota, US and Hambaek in South Korea. Their research was part of the initial International Housing Productivity Study (IHPS), which attempted to test the hypothesis that improved housing conditions raise worker productivity, lower absenteeism from work, lower the need for health services, increase the productivity of education and reduce social ills. Their study compared households before and after they were re-housed. The initial results, which were quantified, showed positive effects on a number of the variables tested including improved work efficiency and health status, the latter of which resulted in fewer days lost from work. On the basis of these results the authors concluded that "housing is truly an economic investment in its right," and "it is profitable as well" (Burns \& Tjioe, 1967: p. 87). These studies and others helped to change the stereotypic image of housing, at least in theory. The question then is what economic effects could housing investment and its associated stream of services have on a national economy?

\section{Economic significance of housing}

Housing markets and housing construction in various economies have served as an engine of growth. The housing sector has typically played a leading role in the process of economic recovery from depression. This is especially true in wealthier societies, notably the US and Japan. For example, Green's (1997) study of business cycles in the US between 1959 and 1992 found that housing leads the business cycle, ahead of all other investments. In Japan, Hirayama (2003) mentioned the use of public housing activities and housing loans as a macro-economic stabilizer to increase demand and create employment during recessions in the 1970s and 1990s. Other countries, such as Thailand and Singapore, have also used investment in housing as a recovery measure (see Sheng \& Kirinpanu, 2000; Phang, 2001). A key advantage of housing is that it is a domestic sector, and as such is protected from 
external influences. Therefore, it could be used to achieve short and long-term economic objectives.

Many authors, for example, believe that mass construction of housing is a key element of Japan's rapid economic growth since the mid-1950s (see Wasco, 2002; Hirayama, 2003: p. 141). In Japan, government expenditures in housing construction have been high. The government has pursued a deliberate policy of encouraging mass housing construction to stimulate the national rate of growth (Hayakawa, 2002; Hirayama, 2003), and an average of between 7 and 9\% of GDP each year has been devoted to housing construction. Expansion of home-ownership has been a core element of housing policy, mainly because it promotes economic growth and encourages savings and investment (Hayakawa, 2002; Hirayama, 2003). As of 1998, the home-ownership rate in Japan was about $60 \%$.

A similar policy approach has been pursued in Asian NICs, notably Singapore, Hong Kong, South Korea and Taiwan. In the development plans of these countries, produced every 5 or 10 years, housing has consistently retained a highprofile, mainly because the governments of these NICs recognized housing as a foundation of economic growth (Doling, 1999, 2002). Consequently, housing enjoyed a high-priority, supported by policies with strong economic logic: housing generates economic growth, creates wealth, creates employment and income, redistributes income and serves as a macro-economic stabilizer during periods of recession (see Doling, 1999; Mera \& Heikkila, 1999; Tu, 1999; Phang, 2001; Agus et al., 2002). As Forrest, Lee, and Wah (2000: p. 7) noted: "like it or not, housing for the masses in the last two decades has become an engine of growth for many Asian cities, such as Singapore and Hong Kong." In particular, the residential property market has enjoyed considerable growth, with varying economic implications. In Hong Kong, the property sector contributed about $24 \%$ to GDP in the 1980s and 1990s. Construction and real estate employed $7 \%$ of the labour force in the mid-1990s, provided substantial revenues for government and wealth for individuals, and was a vital element of the stock markets (see Walker, 1990; Tang, 1998; Haila, 2000).

The Singapore experience is particularly worth elaboration. As a newly independent state in 1959, Singapore faced economic and urban problems, including severe housing shortages that some commentators described as one of the worst in the world (see Kaye, 1960). The Singapore government recognized that an effective housing policy was needed to solve the housing shortage and to promote economic development. Public housing programmes were operated as a part of an economic development package and supported with deep financial commitment. Expenditures averaged between 7.2 and $8.9 \%$ of GDP in the 1970s, and about $15 \%$ in the 1980s and 1990s (see Wong \& Yeh, 1985; Pugh, 1996; Park, 1998; Hirayama, 2003). Not surprisingly, the sector's contributions to the economy have been staggering. By the mid-1980s, $70 \%$ of the total population had access to the Housing and Development Board's (HBD) flat, rising close to $90 \%$ in the 1990 s (Wong \& Yeh, 1985; Pugh, 1997; Phang, 2001; Lee, Forrest, \& Tam, 2003). This high-rate can be attributed to the implementation of the "Home Ownership for the People Scheme" introduced in 1964. The aim of this scheme was "to encourage a property-owning democracy in Singapore, and to enable Singapore citizens in the lower middle-income group to own their own homes" (Goh, 1989: p. 150). Deliberate efforts were made to sell most government flats built since the 1970s. Through the introduction in 1968 of the "Central Provident Fund", a 
public housing finance instrument, citizens were able to buy their own homes. The scheme also allowed for effective mobilization of financial resources and creation of a direct link between the housing system and broader financial markets (Tu 1999; Phang, 2001).

In the 1960s and 1970s, housing contributions to the GDP averaged almost 10.5, rising to $15.5 \%$ in the $1980 \mathrm{~s}$ and $1990 \mathrm{~s}$. When coupled with substantial contributions to capital formation, housing contributions usually accounted for $20-30 \%$ of all contributions to the GDP. Construction of mass housing regulated labour supply and generated a substantial amount of new jobs, especially for women whose participation rates increased from 29.5 to $44.5 \%$ between 1970 and 1980 (Yuen, 2002: p. 48). Housing has a strong link with other sectors of the economy-generating economic growth multipliers of $2 \%$ (Goh, 1989; Phang, 2001). Public housing programmes, according to Lee, Yuan, and, Poh (1993), were linked to "savings and investment process in the economy", and they "formed the very basis for industrialization and human and capital productivity" (cf. Goh, 1989; Salaff, 1997: p. 234; Tu, 1999).

Discussion about housing and economic growth has been filled with disagreement about the direction of causality: does housing a cause economic growth or is an improvement in housing an outcome of growth? It is difficult to determine, and past attempts have proved inconclusive (see, Strassman, 1970a, b; Turin, 1970, 1974, 1978a, b; Drewer, 1980). However, the experiences of Japan and other Asian NICs as noted above may provide a partial answer to this question. In these countries, housing has been an integral part of the growth strategies since the end of the World War II when their economies were shattered. Thus, it is fair to argue that housing is a cause of and a valuable contributor to growth. It is not simply a shelter but rather an investment good that must be taken seriously in any economy. Its economic significance in developing countries is discussed below.

\subsection{Contributions to economic growth}

Construction of mass housing has not been a prominent feature of economic growth strategies of countries, yet the sector has made a substantial contribution to GDP and GFCF and has served as a catalyst for investment in other sectors. Since the 1970s several studies have examined the relationship between construction and economic growth (examples: Strassman, 1970b; Turin, 1978a, b; Drewer, 1980; Wells, 1984, 1985; UNCHS/ILO, 1995). Turin (1978a, b) and Strassman (1970b) argued that a close and dynamic relationship exists between construction output and level of development, and that in most cases a rapid construction output tends to correlate with rapid economic growth. These two researchers demonstrated that a welldefined relationship between construction and economic growth indicates the critical role of construction and housing in the development process. In most developing countries, the construction sector contributes between 3 and $8 \%$ to GDP, a third of which is said to originate from housing (Sethuraman, 1985; UNCHS/ILO, 1995), while the sector's contribution to GFCF is estimated to vary between 40 and $70 \%$ (Moavenzadeh, 1987; UNCHS/ILO, 1995). The true importance of housing is even greater than these data suggest, especially in developing countries since informal activities, which constitute about $80 \%$ of residential construction, are not usually reported or are greatly undervalued (Grimes, 1976). 


\subsection{Housing and employment}

Housing construction has played the important role in urban economies of developing countries by creating employment, especially for unskilled labour. The construction and house building industries have both constituted a "port of entry" to urban labour markets. In Ghana and in the Philippines, for example, Arku (2006) and Stretton (1981) showed that the building industry provides an important source of jobs for both skilled and unskilled migrants from the countryside. In his work for the World Bank, Grimes (1976) showed that an investment in housing programmes, especially low-income housing, is critical because it has the potential to draw large amounts of unused or underused labour into production. Grimes further observed that housing construction in developing countries could be used as a strategy to absorb slack in investment and employment. Studies have estimated that the construction sector, of which residential construction usually constitutes about a third, accounts for $\sim 7 \%$ of the total labour force in developing nations (Moavenzadeh, 1987; Spence et al., 1993). However, total employment generated in construction, including subsidiary activities, may include closer to $10 \%$ of the economically active population (Sethuraman, 1985). Construction activities generated about the same levels of employment, or more, than sectors traditionally regarded as productive and mainstays of developing economies. Grimes (1976: p. 32) indicated that in Columbia the "rate of employment creation in housing construction was higher than that for manufacturing and close to that for the economy as a whole".

The central issue is not the amount of employment created by investment in housing as compared to other sectors. It is the effectiveness of residential construction in creating additional jobs through forwards and backwards linkages in related sectors, such as industry. The building industry has a high potential for employment generation, not only through on-site activities but also through off-site activities (e.g., land surveying, draughtsmen, building materials production and marketing and distribution of construction materials and equipment). Based on his research Grimes (1976) estimated that low-income residential construction could have a multiplier effect of about 2\%, similar to Moavenzadeh's (1987) estimation of a multiplier effect of about two for developing countries-that is, for every job created in construction, two are created elsewhere. Gorynski also stated that "the building industry purchases almost three times as much material from the non-industrial sector of the economy as does manufacturing"' (cited in Drakakis-Smith, 1981: p. 34).

Even though residential construction may be a potential contributor to employment and a significant purchaser of goods and services from other sectors of the economy, the extent to which it can generate employment and enhance growth largely depends on a number of factors, notably the choice of technology (e.g., type of labour and materials used). Spence and Cook (1983) identify three types of technology: "low", "intermediate" and "high". They argue that intermediate technology constitutes the appropriate technique for developing countries. These terms were first used by Schumacher (1973). The basis of his distinction was the amount of capital investment required to support a given project, which was argued to be a critical factor in the planning of all developing countries. Like Schumacher (1973) and Spence and Cook (1983) justified the use of capital as a basis for categorizing various technologies because it directly affects the amount of employment generated. 
"Low" technologies are those that have a strong local content; they use locally produced raw resources, are quite cheap to establish and can be adaptable to different conditions. On the other hand, they are relatively inefficient in the way they use labour and raw material, and the goods produced are mostly of poor quality. Unlike "low" technology, "high" technology requires a large capital investment and substantial imported materials and the methods of production are complex. For example, this designation applies to the current method of producing cement, steel and aluminum (Spence \& Cook, 1983: p. 3). "High" technologies generate little employment and produce sophisticated, high-priced goods. "Intermediate" technologies are based on a mix of locally produced and imported raw materials. In terms of capital, "intermediate" technologies require a higher level of capital investment than "low" technologies but substantially lower investments than "high" technologies. The main advantages of "intermediate" technologies are their lowcost, small scale and, more importantly, the use of relatively simple production methods (Spence \& Cook, 1983: pp. 5-7). Such technologies involve processing local raw materials and generating wider employment, and they are relatively independent of large, imported materials.

The case for "intermediate" technologies in places like Africa is particularly strong. Over the last three decades about $60 \%$ of the imported materials used in the building and construction industries were imported, which limited employment generation and potential linkages with other sectors of the economy (Edmonds, 1979; UNCHS/ILO, 1995). Meanwhile, a survey carried out in Sri Lanka by Ganesian (1982) found a higher employment rate in cheaper, small-scale technologies than in "high" technologies. Under current precarious economic conditions, including critical unemployment in most developing countries, there is the need to adopt techniques that are appropriate and cost-effective. This might include a blend of locally produced materials and foreign input. In this respect, "intermediate" technologies are vital. Fortunately, local resources for such technologies and the required expertise already abound (Spence \& Cook, 1983). While this argument applies to construction in general, it applies specifically to residential, low-cost housing construction using locally manufactured materials.

\subsection{Savings and domestic financial mobilization}

In low-and middle-income settlements in Third World cities, the home is used not only for shelter but also as a source of income through HBEs and rental arrangements. These activities are prevalent in cities of many developing countries and serve as vital sources of employment and income for low-income people. They also contribute to national income and, therefore, the economic development process. McCallum and Stan (1985: p. 286) concluded that "Housing has a complex and vital economic role in low-income communities in Third World cities well beyond that normally attributed to it in conventional economic thought and practice". The authors' conclusion was based on empirical studies that identified the home and its environment as a place filled with economic activities, such as carpentry and furniture works, food-selling, tailoring and shoemaking (McCallum \& Stan, 1985: p. 281). A similar conclusion was reached by Tipple (1993) who demonstrated that HBEs are common and vital income-generating activities in cities of developing countries. Strassman (1987) surveyed low-income settlements in Lusaka (Zambia), Colombo 
(Sri Lanka) and Lima (Peru) to determine the share of employment generated by HBEs and their contribution to urban households. His study revealed a strong presence of HBEs (e.g., sewing, cooking and repairs) that served as vital sources of employment and income. For example, about $25 \%$ of the total households surveyed in Lusaka had HBEs, as did households in Colombo. His study showed that households with enterprises had incomes more than $10 \%$ higher than those with no enterprise.

The prevalence of HBEs has also been reported in recent studies. In Egypt, 53\% of women's and $10 \%$ of men's businesses are located in the home (cited in Chen et al., 1999). In Venezuela, 45\% of all clothing industry workers are homed-based (cited in Chen et al., 1999). Fisseha and McPherson (1991) reported that $71 \%$ of enterprises in South Africa are either located in the home or are home-based.

Apart from HBEs, home-owners in low-income and middle-income areas used their homes to generate income through renting. Kumar (1996) demonstrated that the production of renting accommodations is extensive. It is economically vital for most cities in developing counties and is a profitable business for most landlords. Hoffman et al., for example, found that $30 \%$ of the residents in kampongs in Indonesia are tenants (cited in Kumar, 1996). Sinai (1998) found that the use of homes for renting was widespread in Kumasi (Ghana), with $60 \%$ of all households surveyed renting their rooms.

While many of these empirically based studies reiterate the economic benefits of housing investments, they also question the old theory that a house is purely a consumer item. For most people living in low-and middle-income areas, the house is their work place, thus making the case that housing can be considered a productive investment that NDPs should consider. Whether measured in terms of work hours or value of production, investment in housing ought to be treated as productive and should be tied to national policies aimed at creating employment for the growing population.

The role of housing assumes even a greater economic significance when saving is considered. The development of housing finance systems can constitute an essential means of mobilizing financial resources for the development of the domestic economy. The rate of saving in most developing countries is low, due to low incomes and more especially due to the lack of well-organized financial institutions. This situation has compelled households to hold savings in unproductive assets like gold and jewellery. At the same time, most people tend to attach a high priority to homeownership. Home-ownership is one of the highest priorities in terms of asset acquisition for the majority of people in developing countries, and many people are prepared to make sacrifices in other areas in order to purchase a house. If these resources can be mobilized and properly channelled, a housing finance system could become an important instrument for the under-utilized funds of the household sector and could serve as a tool for the development of both the financial system and the domestic economy.

\subsection{Housing and health effects}

Researchers have long recognized a link between housing and health. This link was a crucial factor in public health reforms in many developed countries during the 19th century. This is true for countries such as Britain, where health concerns lay at the 
heart the Public Health Acts of the late 19th century (Easterlow, Smith, \& Mallinson, 2000). In several developing countries, early housing policies were shaped by various health considerations, even though much of the concern was for preventing the spread of disease to elite areas. Studies on housing and health have singled out features of the housing environment that pose serious direct or indirect threats to the physical and mental health of people. The most important of these are overcrowding, location, tenure and housing conditions.

Researchers have pointed out that a high level of household crowding can produce stress leading to illness and that congestion ensures easy transmission of communicable diseases (Fuller, Edwards, Sermsri, \& Vorakitphokatorn, 1993; Caincross et al., 1990). A study carried out in the town of Olaleye-Iponri, Nigeria, by Aina (1990) found a strong association between overcrowding and the prevalence of disease. Cuenya et al. (1990) found a similar association in Buenos Aires, Argentina. Studies have also associated housing tenure with health. One relevant finding is that those who rent their houses have poorer health than those who own their houses (Macintyre, Hiscock, Kearns, Ellaway, 2001). Caincross et al. stated that "the fact that many (poor) urban dwellers live in illegal settlements and are subject to a constant threat of eviction also has serious health impacts..." (Caincross, Hardoy, \&, Satterwaithwaite 1990). Indeed, for most of the developing world, recent cuts in government expenditures on infrastructure and social services, coupled with the dwindling purchasing power of poorer groups, have further exacerbated poor housing conditions (e.g. poor sanitation, low state of repair) and poor location (mostly "illegal" settlements) and have decreased housing tenure. All of these have been identified as powerful indicators of poor health (cf. Hyndman, 1998; Macintyre et al., 2001). Increased productivity is essential for economic growth, but population health has a crucial influence on productivity. Health, in turn, depends on living conditions-notably housing. This suggests that housing and related services are not just social or welfare issues but economic issues as well.

Housing investment should not be considered as a resource-absorbing, unproductive sector or merely as a social policy with little or no effect on other sectors of an economy. Instead, housing should be viewed as a resource producing and investment good. The economic benefits of housing need to be considered and planned for as a necessary component of wider national development strategies.

\section{Concluding comments}

We have come a long way in our understanding of the relationship between housing and economic development since the debate began in the early 1950s. At the beginning the issue seemed straightforward: housing was a "non-productive" element of development strategies. As such, investment needed to be made in basic facilities and industries to build economies, which would, in turn, generate sufficient growth for housing to thrive as an industry. Since then, housing experts have emphasized the significance of housing in economic development. International institutions such as the World Bank, which initially opposed investment in housing, shifted their position in the late 1960s and 1970s and have become strong advocates of housing as an economic development tool. In the majority of developing countries, however, this new perception has yet to take hold. The status quo is being maintained 
by placing the highest priority on strategies that promote rapid economic growth, primarily policies that attract foreign direct investment and trans-national corporations and the creation of export processing zones. Although many urban areas are experiencing tremendous growth, housing is still being addressed as if it were a passive element in economic development. This inadequate attention has exacerbated the poor and inadequate housing situations of most cities and has severely compromised economic development programmes.

The experience of Japan and Asian NICs since the 1960s offers valuable lessons for policy-makers in less-developed countries. First, strong government intervention in the form of comprehensive policies and large-scale investments will be necessary. Second, housing policies have to be operated as part of economic development strategies, and the objectives of such strategies must look beyond welfare considerations. Indeed, in Singapore and other NICs, housing policies have been designed to meet the housing needs of the entire population. More importantly, these policies recognize housing as a leading economic sector. Housing policies have been pursued with zeal and financial commitment. They have been linked to the savings and investment process and have formed the basis of industrial development. Admittedly, the Asian NICs have unique features. They are small geographically, with relatively small populations and their model may not be replicated easily in other economies. Despite these features, their approach offers many useful general lessons. In particular, they teach that housing is a part, rather than a by-product, of the economic development process. And because of this fact, housing can contribute substantially to economic development.

\section{References}

Agus, M. R., Doling, J., Lee, D.-S. (2002). Housing policy systems in south and east Asia. Palgrave: McMillan.

Arku, G., \& Harris, R. (2005). Housing as a tool of economic development since 1929. International Journal of Urban and Regional Research, 29(4), 895-915.

Arku, G. (Forthcoming, 2006). Housing and development strategies in Ghana, 1945-2000. International Development Planning Review.

Abrams, C. (1964). Housing in the modern world. London: Faber and Faber.

Aina, T. K. (1990). Housing and Health in olaleye-iponri, a low-income settlement in lagos, Nigeria. In S. Caincross, J. E. Hardoy, \& D. Satterwaithwaite (Eds.), The poor die young: housing and health in third world cities. London: Earthscan Publications Ltd.

Bauer, C. (1955). The case for regional planning and urban dispersal. In B. Kelly (Eds.), Housing and economic development. school of architecture and planning. MA: Institute of Technology.

Buckley, R., \& Mayo, S. (1988). Housing policy in developing economies: Evaluating the macroeconomic impacts. The World Bank Discussion Paper. Washington, DC.

Burns, L. S., \& Grebler, L. (1977). The housing of nations: Analysis and policy in comparative framework. New York: Wiley.

Burns, L. S., \& Tjioe, B. K. (1967). Does good housing contribute to sound economic development? The Journal of Housing, 24(2), 86-89.

Caincross, S., Hardoy, J. E., \& Satterwaithwaite, D. (1990). The poor die young: housing and health in Third World cities. London: Earthscan Publications Ltd.

Chen, M., Sebstad, J., \& O'Connell, L. (1999). Counting the invisible workforce: The case of homebased workers. World Development, 27(3), 603-610. 
Christian, J. W. (1987). The contribution of shelter to national economic development. In Proceedings of the Second International Shelter Conference and Vienna Recommendations on Shelter and Urban Development (pp. 50-55). IYSH, Vienna.

Cuenya, B., Almada, H., Armus, D., Castels, J., Loreto, M., \& Penalva, S. (1990). Community action to address housing and health problems: The case of San Martin in Buenos Aires, Argentina. In S. Caincross, J. E. Hardoy, \& D. Satterwaithwaite (Eds.), The Poor die young: housing and health in third world cities. London: Earthscan Publications Ltd.

Currie, L. (1966). Accelerating development: The necessity and the means. New York, London, Sydney, Toronto: McGraw-Hill Book Company.

Drakakis-Smith, D. (1981). Urbanization, housing and the development process. London: Croom Helm.

Drakakis-Smith, D. (1997). Third World cities: Sustainable urban development iii-basic needs and human rights. Urban Studies, 34(5-6), 797-823.

Drewer, S. (1980). Construction and development: A new perspective. Habitat International, 5(3/4), 395-428.

Doling, J. (1999) Housing policies and the little tigers: how do they compare with other industrialized countries. Housing Studies, 14(2), 229-250.

Doling, J. (2002) The south and east Asian housing model. In M. R. Agus, J. Doling, \& D.- S. Lee (Eds.), Housing policy systems in south and east Asia. Palgrave: Macmillan.

Domar, E. (1947). Expansion and employment. American Economic Review, 37(1), 34-55.

Easterlow, E., Smith, J. S., \& Mallinson, S. (2000). Housing and health: The role of the owner OCCUPATION. Housing Studies, 15(3), 367-386.

Edmonds, G. A. (1979). The construction industry in developing countries. International Labour Review, 118(3), 355-368.

Fisseha, Y., \& McPherson, M. A. (1991). A country study of Small-Scale Enterprise in Swaziland. GEMINI Technical Report No. 24.

Forrest, R., Lee. J., \& Wah, C. K. (2000). Focus on housing in South-East Asia. editors' introduction. Housing Studies, 15(1), 7-10.

Freeman, J. (1975). Crowding and behaviour. New York: Viking Press.

Fuller, D. T., Edwards, N. J., Sermsri, S., \& Vorakitphokatorn, S. (1993). Housing stress, and physical well-being: Evidence from Thailand. Social Science Medicine, 36(11), 1417-1428.

Ganesian, S. (1982). The construction industry in Sri Lanka. ILO World Employment Programme Working Paper, Geneva, 1982.

Gilbert, A., \& Gugler, J. (1992). Cities, poverty and development: urbanization in the Third World. New York: Oxford University Press.

Goh, E. (1989) Planning that works: Housing policy and economic development in Singapore. JPER, $7(3), 147-162$.

Gorynski, J. (1978). The role of construction in global socio-economic development. Habitat International, 3(1/2), 71-76.

Grebler, L. (1955). Possibilities of international financing of housing. In B. Kelly (Ed.), Housing and economic development. MA: A report of a Conference Sponsored at the Massachusetts Institute of Technology by the Albert Farwell Bemis Foundation.

Green, R. (1997). Follow the leader: How changes in residential and non-residential investment predict changes in GDP. Real Estate Economics, 25(2), 253-270.

Grimes, O. F. Jr., (1976). Housing for low-income urban families economics and policy in the developing world. Baltimore, London: The Johns Hopkins University Press.

Hable-Selassie, S. (1978). Construction estimates and national income accounting in developing countries. In O. H. Koenigsberger, \& S. Groak (Eds.), Essays in memory of duccio Turin (19291976). Oxford, NY: Pergamon Press.

Haila, A. (2000) Real estate in global cities: singapore and hong kong as property states. Urban Studies, 37(12), 2241-2256.

Hardoy, J. (1978). The recommendations of the UN conference on human settlements and their viability in Latin America. In O. H. Koenigsberger, \& S. Groak (Eds.), Essays in memory of duccio Turin (1929-1976). Oxford, NY: Pergamon Press.

Harris, W. D., \& Gillies, J. (Eds.) (1963). Capital formation and housing in Latin America. Washington DC: Pan American Union.

Harrod, R. (1939). An essay in dynamic theory. Economic Journal, 49(193), 14-33.

Hayakawa, K (2002). Japan. In M. R. Agus, J. Doling, \& D.-S. Lee (Eds.), Housing policy systems in south and east asia. Palgrave: Macmillan. 
Hirayama, Y. (2003). Home-ownership in an unstable world. In R. Forrest, \& J. Lee (Eds.), Housing and social change. Routledge, London, NY: Taylor and Francis Group.

Howenstine, J. W. (1957). Appraising the role of housing in economic development. International Labour Review, 75, 21-33.

Hyndman, S. (1998). Making connections between housing and health. In R. Kearns, \& S. Gesler (Eds.) Putting health into place: landscape, identity and well-being. New York: Syracuse University Press.

International Monetary Fund (IMF) (1986). Government financial statistics. Washington, DC.

Kafandaris, S. (1980). The building industry in the context of development. Habitat International, $5(3 / 4), 289-322$.

Kaye, B. (1960) Upper nankin street Singapore: A sociological study of chinese households living in a densely populated area. Singapore: University of Malaya Press.

Kelly, B. (Ed.) (1955). Housing and economic development. MA: A report of a Conference Sponsored at the Massachusetts Institute of Technology by the Albert Farwell Bemis Foundation.

Koenigsberger, O. H. (1970). Housing in the national development plan: an example from Nigeria. Ekistics, 180, 393-397.

Kumar, S. (1996). Landlordism in Third World urban low-income settlements: A case for further research. Urban Studies, 33(4-5), 753-782.

Lee, J., Forest, R., \& Tam, K. W. (2003). Home-ownership in east and south Asia: Market, state and institutions. In R. Forrest, \& J. Lee (Eds.), Housing and social change. Routledge, London, NY: Taylor and Francis Group.

Lee, L. S., Yuan, L. L., \& Poh, K. T. (1993) Shelter for all: Singapore's strategy for full ownership by the year 2000. Habitat International, 17(1), 85-102.

Lewis, W. A. (1954) Economic development with unlimited supply of labour. In A. N. Agawala, \& S. P. Singh (Eds.), The economics of underdevelopment (pp. 400-449). London: Oxford University Press.

Macintyre, S., Hiscock, R., Kearns, A., \& Ellaway, A. (2001). Housing tenure and car access: Further exploration of the nature of their relations with health in a UK setting. Journal of Epidemiology and Community Health, 55, 330-331.

Malpezzi, S. (1990). Urban housing and financial markets: some international comparisons. Urban Studies, 27(6), 971-1022.

McCallum, D., \& Stan, B. (1985). Low income urban housing in the third world: broadening the economic perspective. Urban Studies, 22, 277-288.

McCarthy, P., Byrne, D., Harrison, S., \& Keithley, J. (1985). Housing type, housing location and mental health. Social Psychiatry, 20, 125-130.

Mera, K., \& Heikkila, J. E. (1999). Housing as a means of sustainable economic recovery in southeast Asia. RURDS, 11(2), 82-90.

Millikan, M. (1955). The Economist's view of the role of housing. In B. Kelly (Ed.), Housing and economic development. MA: A report of a Conference Sponsored at the Massachusetts Institute of Technology by the Albert Farwell Bemis Foundation.

Moavenzadeh, F. (1987). The construction industry. In L. Rodwin (Ed.), Shelter, settlement and development (pp. 73-109). Boston: Allen and Unwin.

Nerfin, M. (1965). Towards a housing policy. Journal of Modern African Studies, 3(4), 543-565.

Nurkse, P. A. (1953). Problems of capital formation in underdeveloped countries. Oxford: Oxford University Press.

Park, B.-G. (1998). Where do tigers sleep at night? The state's role in housing policy in south Korea and Singapore. Economic Geography, 74(4), 272-288.

Peattie, L. (1979). Housing policy in developing countries: Two puzzles. World Development, 7, 1017-1022.

Phang, S. Y. (2001). Housing Policy, wealth formation and the singapore economy. Housing Studies, 16(4), 443-459.

Pugh, C. (1996). Urban bias, the political economy of development and urban policies for developing countries. Urban Studies, 33(7), 1045-1060.

Pugh, C. (1997). Poverty and progress? reflections on housing and urban policies in developing countries, 1976-1996. Urban Studies, 34(10), 1547-1595.

Pugh, C. (2001). the theory and practice of housing sector development for developing countries, 1950-1999. Housing Studies, 16(4), 399-423.

Raj, M., \& Mitra, B. (1990). Households, housing and home based economic activities in low income settlements. In M. Raj, \& P. Nientied (Eds.), Housing and low income in third world urban development. London: Aspect Publishing. 
Renaud, B. (1987). Financing shelter. In L. Rodwin (Ed.), Shelter, settlement, and development. Boston: Allen Unwin.

Robinson, H. (1963). Inter-American housing financial sources and policies. In W. Harris, \& J. Gillies (Eds.), Capital formation and housing in Latin America. Washington DC: Pan American Union.

Rodwin, L. (Ed.) (1987). Shelter, settlements, and development. Boston: Allen Unwin.

Rostow, W. W. (1960). The stages of economic growth. A non-communist manifesto. England: Cambridge University Press.

Salaff, J. W. (1997). Social policy transforms the family: The case of Singapore. In J. Gugler (Ed.), Cities in the developing world: issues theory, and policy. Oxford: Oxford University Press.

Samuelson, A. P. (1955). The dilemmas of housing. In W. Harris, \& J. Gillies (Eds.), Capital formation and housing in Latin America. Washington DC: Pan American Union.

Sethuraman, S. V. (1985). Basic needs and the informal sector: The case of low-income housing in developing countries. Habitat International, 9(3/4), 299-316.

Schumacher, E. F. (1973). Small is beautiful. London: Blond and Briggs.

Sheng, Y. K., \& Kirinpanu, S. (2000) Once only the sky was the limit: Bangkok's housing boom and the financial crisis in Thailand. Housing Studies, 15(1), 11-27.

Sinai, I. (1998). Using the home for income-generating: The case of Kumasi, Ghana. Cities, 15(6), 417-427.

Solow, A. A. (1955). The importance of housing and planning in Latin America. In B. Kelly (Ed.), Housing and economic development. MA: A report of a Conference Sponsored at the Massachusetts Institute of Technology by the Albert Farwell Bemis Foundation.

Spence, R., Wells, J., \& Dudley, E. (1993). Jobs from housing: employment, building materials and enabling strategies for urban development. London: Intermediate Technological Publications.

Spence R., \& Cook, D. J. (1983). Building materials in developing countries. Chichester, New York, Toronto, Brisbane, Singapore: Wiley.

Strassman, W. P. (1970a). Construction productivity and employment in developing countries. International Labour Review, 101, 503-518.

Strassman W. P. (1970b). The Construction sector in economic development. Scottish Journal of Political Economy, 17, 391-409.

Strassman, W. P. (1982). The transformation of urban housing. Baltimore: The Johns Hopkins, University Press.

Strassman, W. P. (1985). Employment in construction: multi-country estimates of costs and substitution elasticities for small dwellings. Economic Development and Cultural Change, 33(2), 395414.

Strassman, W. P. (1987). Home-based enterprises in cities of developing countries. Economic Development and Cultural Change, 36(1), 121-144.

Stretton, A. W. (1981). The building industry and urbanization in third world countries: a philippine case study. Economic Development Cultural Change, 29(2), 121-144.

Syagga, P. M. (1987). Myths and realities of low cost housing in Africa. African Urban Quarterly, 2(3), 202-211.

Tang, B. S. (1998). Property development process in Hong Kong. In T.N.T. Poon, \& E.H.W. Chan (Eds.), Real estate development in Hong Kong. Hong Kong: Pace Publishing.

Tipple, G. (1987). Employment from housing: a resource for rapidly growing urban population. Cities, 11(6), 372-376.

Tipple, G. (1993). Shelter as workplace: A review of home-based enterprise in developing countries. International Labour Review, 132, 521-539.

Tu, Y. (1999). Publish homeownership, housing finance and socioeconomic development in Singapore. RURDS, 11(2), 100-113.

Turin, D. A. (1970). Construction and development. Habitat International, 3(1/2), 33-45.

Turin, D. A. (1974). The role of construction in development strategies. International Development Review, XVL(3), 19.

Turin, D. A. (1978a). Construction and development. Habitat International, 3(1/2), $33-45$.

Turin, D. A. (1978b). It had to be said. In O. H. Koenigsberger, \& S. Groak (Eds.), Essays in memory of Duccio Turin (1929-1976). Oxford: Pergamon Press.

Turner, J. F. C. (1968). Housing priorities, settlements patterns and urban development in modernizing countries. Journal of the American Institute of Planners, 33, 354-363.

Turner, J. F. C. (1976). Housing by people. London: Marion Boyars Publishing.

Turner, J. F. C. (1978) Housing in three dimensions: terms of reference for the housing question redefined. World Development, 6(9/10), 1135-1145. 
Turner, J. F. C., \& Fichter, R. (Eds.) (1972). Freedom to build. New York: Collier-Macmillan. United Nations. Economic and Social Commission (EcoSoc, 1955), International Action in Asia and Far East. ST/SOA/SER.C/9. New York.

United Nations (1969). United nation industrial development organization (UNIDO) (1969) construction industry. New York.

United Nations (1973). Integration of housing into national development plans: a systems approach. UN ST/ECA/185. New York.

UNCHS/ILO (1995). Shelter provision and employment generation. Geneva: ILO Office.

Van Hyck, P. (1987). The economics of shelter provision. Address to the Second International Shelter Conference. Vienna, Austria.

Walker, A. (1990). hong kong: property construction and the economy. London: Royal Institute of Chartered Surveyors.

Wasco, A. (2002). Housing in postwar japan: a social history. RoutledgeCurzon: Taylor \& Francis Group.

Wegelin, E. A. (1978). Urban low-income housing and development: A case study in Peninsular Malaysia. Leiden: Martinus Nijhoff Social Sciences Division.

Weissmann, E. (1955). Importance of physical planning in economic development. In B. Kelly (Ed). Housing and economic development. MA: A report of a Conference Sponsored at the Massachusetts Institute of Technology by the Albert Farwell Bemis Foundation.

Wells, J. (1984). The construction industry in the context of development: a new perspective. Habitat International, 8(34), 9-28.

Wells, J. (1985). The role of construction in economic growth and development. Habitat International, 9(1), 55-70.

Wong, A. K., \& Yeh, S. H. K., (Eds.) (1985) Housing a nation: twenty-five years of public housing in Singapore. Singapore: Maruzen Asia.

World Bank (1993). Housing. enabling the markets to work. Washington D.C.: World Bank.

Yuen, B. (2002) Singapore. In M. R. Agus, J. Doling, \& D.-S. Lee (Eds.), Housing policy systems in south and east Asia. Palgrave: Macmillan. 